University of Nebraska - Lincoln

DigitalCommons@University of Nebraska - Lincoln

\title{
Comparison of Restriction Fragment Length Polymorphisms in Chloroplast DNA of Five Leafy Spurge (Euphorbia spp.) Accessions
}

\author{
Scott Nissen \\ University of Nebraska-Lincoln \\ Robert A. Masters \\ University of Nebraska-Lincoln, rmasters1@unl.edu \\ Donald Lee \\ University of Nebraska-Lincoln, dlee1@unl.edu \\ Martha Rowe \\ University of Nebraska-Lincoln
}

Follow this and additional works at: https://digitalcommons.unl.edu/usdaarsfacpub

Part of the Agricultural Science Commons

\footnotetext{
Nissen, Scott; Masters, Robert A.; Lee, Donald; and Rowe, Martha, "Comparison of Restriction Fragment Length Polymorphisms in Chloroplast DNA of Five Leafy Spurge (Euphorbia spp.) Accessions" (1992). Publications from USDA-ARS / UNL Faculty. 1083. https://digitalcommons.unl.edu/usdaarsfacpub/1083
}

This Article is brought to you for free and open access by the U.S. Department of Agriculture: Agricultural Research Service, Lincoln, Nebraska at DigitalCommons@University of Nebraska - Lincoln. It has been accepted for inclusion in Publications from USDA-ARS / UNL Faculty by an authorized administrator of DigitalCommons@University of Nebraska - Lincoln. 


\title{
Comparison of Restriction Fragment Length Polymorphisms in Chloroplast DNA of Five Leafy Spurge (Euphorbia spp.) Accessions ${ }^{1}$
}

\author{
SCOTT J. NISSEN, ROBERT A. MASTERS, DONALD J. LEE, and MARTHA L. ROWE2
}

\begin{abstract}
Chloroplast DNA (cpDNA) restriction fragment length polymorphisms (RFLPs) were analyzed to assess genetic variation and relatedness among selections of North American and Eurasian leafy spurge. Leafy spurge accessions from Nebraska, Montana, Russia, Italy, and Austria were evaluated. Total DNA was extracted from young leaves and digested with the restriction endonuclease, EcoRI. CpDNA fragment patterns were determined by Southern blot analysis using mung bean cpDNA probes. Colinearity between the mung bean and leafy spurge chloroplast genomes was indicated by the observation that common fragments were hybridized by adjacent probes. Minimum estimates of chloroplast genome size for the five leafy spurge accessions, which ranged in kilobase size from 130 to 132 , were within the size range of most terrestrial plants. Structural collinearity and reasonable estimates of chloroplast genome size provided evidence that the mung bean cpDNA library was suitable for characterizing leafy spurge cpDNA. Seven of the 13 mung bean probes hybridized to polymorphic leafy spurge cpDNA fragments. Based on number of polymorphisms unique to each Eurasian accession, the Austrian accession appeared to be most divergent followed by the Italian and Russian. The North American accessions seem to be most closely related to each other and to the Russian leafy spurge accession. Nomenclature: Leafy spurge, Euphorbia esula (L.) \# $\#^{3}$ EPHES; mung bean, Vigna radiata $\mathbf{L}$.

Additional index words: Chloroplast restriction fragment length polymorphism, genetic diversity, genetic relatedness, EPHES.
\end{abstract}

\section{INTRODUCTION}

Leafy spurge has been recognized as the most serious threat to the productivity and quality of rangeland in the northern Great Plains of the United States and Prairie Provinces of Canada (39). This nonendemic species has continued to spread during the past $40 \mathrm{yr}$ despite intensive research and management efforts. Lack of economical chemical control strategies and absence of natural enemies

\footnotetext{
${ }^{1}$ Received for publication February 1, 1991, and in revised form September 24, 1991. Published as Paper No. 9480, J. Ser., Nebraska Agric. Exp. Stn.

${ }^{2}$ Authors are Asst. Prof., Dep. Agron., Univ. Nebraska; Range Sci., U.S. Dep. Agric., Agric. Res. Serv.; Asst. Prof., and Res. Technol., Dep. Agron., Univ. Nebraska, Lincoln, NE 68583.

${ }^{3}$ Letters following this symbol are a WSSA-Approved computer code from Composite List of Weeds, Revised 1989. Available from WSSA, 309 West Clark Street, Champaign, IL 61820.
}

have made leafy spurge in North America a candidate for biological control.

Biological control of leafy spurge has had limited success because of an incomplete understanding of the Eurasian origins of leafy spurge found in North America $(7,11,28)$. Researchers became aware of the importance of establishing this relationship when it was discovered that insects collected in Austria and Switzerland rejected North American leafy spurge as a host (11). This observation suggested that candidate biological control organisms should be collected from areas of Eurasia with the same genotype(s) of leafy spurge found in North America.

The genetic relationship between leafy spurge in North America and Eurasia has not been established. There has been little success using morphological traits (7), cytogenetic measurements (33), and analysis of secondary chemical compounds $(12,14,16,37)$ as criteria to determine this relationship.

Attempts to classify leafy spurge using morphological traits have confused, rather than clarified, the relatedness of North American and Eurasian leafy spurge. The same leafy spurge specimen was identified as $E$. virgata Wald. \& Kit. (17), as E. esula L. (40), and E. waldsteinii (Sojak) (27). It was suggested that the characteristics used to differentiate between $E$. esula and $E$. virgata merged such that the species were indistinguishable (1). Most of the 19 morphological traits used to distinguish between 39 accessions of leafy spurge from the United States, Canada, and Austria were inadequate as criteria to establish relatedness (7).

Cytogenetic studies conducted to determine the relationships within Euphorbia spp. in North America and Eurasia also were found to be unsatisfactory (33). Classification of the polyploids present within the North American complex of leafy spurge was weakened because the progenitors were unknown. Progenitors must be known to establish chromosome associations before cytogenetic classification can be utilized (10).

Micromolecular chemosystematic criteria used to differentiate among members of the leafy spurge complex include variation in epicuticular waxes (16) and latex chemical composition $(12,14,37)$. Five leafy spurge biotypes had similar hydrocarbon composition and differed mainly in triterpenoid content (16). Latex samples analyzed by Curiepoint pyrolysis-gas chromatography coupled with multivariate analysis techniques have been used in an attempt to characterize accessions of leafy spurge (37). This method was able to separate $E$. esula from $E$. cyparissias but did not clearly differentiate North American biotypes of leafy spurge. Latex triterpenoid composition was highly variable and could not be used to discriminate between 27 Montana and 15 European leafy spurge accessions (12). The basis of triterpenoid inheritance and influence of environment on 
Table 1. Sources of leafy spurge accessions evaluated in this study.

\begin{tabular}{lllll}
\hline $\begin{array}{l}\text { USDA-ARS } \\
\begin{array}{l}\text { accession } \\
\text { number }\end{array}\end{array}$ & $\begin{array}{l}\text { State or } \\
\text { country }\end{array}$ & Town & Contributor & Location \\
\hline FD-6 & Nebraska & Lincoln & R. Masters & Agronomy Department, University of Nebraska, Lincoln, NE \\
FD-7 & Montana & Bozeman & P. Fay & Plant \& Soil Science, Montana State University, Bozeman, MT \\
FD-38 & Russia & Stavropol & R. Bennet & USDA-ARS Foreign Disease, Weed Science Research Unit, Fort Detrick, MD \\
FD-39 & Italy & Pisa & R. Bennet & USDA-ARS Foreign Disease, Weed Science Research Unit, Fort Detrick, MD \\
FD-13 & Austria & Krems & R. Lym & Agronomy Department, North Dakota State Univ., Fargo, ND \\
\hline
\end{tabular}

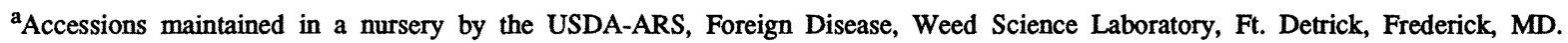

triterpenoids must be understood before latex triterpenoid composition could be reliably used as criteria to distinguish among leafy spurge biotypes (14).

A macromolecular chemosystematic technique, restriction fragment length polymorphism (RFLP) ${ }^{4}$ analysis of chloroplast DNA (cpDNA) ${ }^{4}$, can be used to assess intra- and interspecific genetic variability and has been particularly useful where multiple hybridizations have occurred (19). The utility of cpDNA polymorphism analysis for purposes of classification has been demonstrated with Pisum (20), Lycopersicon (25), Nicotiana (13, 31), Triticum-Aegilops (3, 36, 38), Brassica-Raphanus (8, 22), Cucumis (26), Linum (4), and Clarkia and Heterogaura (35).

Several factors make cpDNA simpler to study than nuclear DNA (nDNA) ${ }^{4}$ and mitochondrial DNA (mtDNA) ${ }^{4}$. The chloroplast genome, in contrast to nuclear and mitochondrial DNA (19), is smaller, has a highly consistent gene order (18, 41), contains a relatively small amount of repetitive DNA, and is highly conserved. Nucleotide substitutions occur at a relatively slow rate in cpDNA compared to nDNA $(5,18,24$, 34).

Analysis of cpDNA polymorphisms is an effective tool for classifying plant species where introgression has occurred (19). Size and stability of the chloroplast genome of land plants, and its intermediate rate of nucleotide substitution, make it suitable for investigations mainly at and above the species level. Therefore, the objectives of this study were to establish the existence of cpDNA polymorphisms in Eurasian and North American leafy spurge and to determine if cpDNA polymorphisms could be used in establishing the Eurasian origin of North American leafy spurge.

\section{MATERIALS AND METHODS}

Plant material. Leafy spurge accessions from Nebraska,

\footnotetext{
${ }^{4}$ Abbreviations: RFLP, restriction fragment length polymorphism; cpDNA, chloroplast deoxyribonucleic acid; nDNA, nuclear deoxyribonucleic acid; mtDNA, mitochondrial deoxyribonucleic acid.

${ }^{5}$ RA-PID-GRO. Chevron Chem. Co., San Ramon, CA.

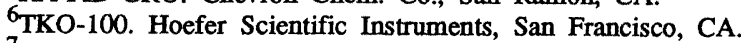

${ }^{7}$ American Hoechst Corp., Somerville, NJ.

${ }^{8}$ Promega Biotec, Madison, WI.

${ }^{9}$ Model SGE-014. C.B.S. Scientific, Delmar, CA.
}

Montana, Russia, Italy, and Austria were obtained for evaluation in this study (Table 1). The nonendemic North American and endemic Eurasian accessions were single clones representing geographically separate populations of leafy spurge. Plants were propagated from adventitious crown buds planted in a 1:1 mixture by vol of Sharpsburg silty clay loam and sand soil contained in 12-L plastic pots. Plants were placed in a greenhouse, surface watered as needed, and provided with $500 \mu \mathrm{E} \mathrm{m}^{-2} \mathrm{~s}^{-1}$ supplemental lighting from mercury vapor lamps to supply $12 \mathrm{~h}$ of light. Every $14 \mathrm{~d} 200$ $\mathrm{mg}$ of a complete fertilizer ${ }^{5}$ was applied to each plant in 250 $\mathrm{ml}$ of water. Plant topgrowth was removed at 45-d intervals to stimulate growth of the young tissue needed for analysis. DNA extraction, restriction endonuclease digestion, and gel electrophoresis. Young leaves were removed from plants and lyophilized, and total DNA was extracted (30). Total DNA samples were quantified in a fluorometer ${ }^{6}$ with DNA specific dye Hoechst $33258^{7}$. DNA samples were digested to completion with $E c o \mathrm{RI}^{8}$ following supplier's instructions. Approximately $10 \mu \mathrm{g}$ of digested total DNA was loaded into each lane of a $25-\mathrm{cm}$ gel containing $8 \mathrm{~g} \mathrm{~L}^{-1}$ agarose. Electrophoresis was conducted on a horizontal apparatus ${ }^{9}$ at 1 $\mathrm{V} \mathrm{cm}-1$ for $23 \mathrm{~h}$ in TBE gel buffer [ $(0.089 \mathrm{M}$ Tris, $0.089 \mathrm{M}$ boric acid, and $0.002 \mathrm{M}$ ethylenediaminetetracetic acid (EDTA)] (15). Gels were stained with ethidium bromide and photographed under ultraviolet light. Mobilities of HindIIIdigested Lambda DNA markers were measured from the photographs.

Southern blot transfers. Transfer of restriction fragments from agarose gels to nylon membranes was performed according to Reed and Mann (29). After transfer, membranes were baked at $80 \mathrm{C}$ for $2 \mathrm{~h}$.

Hybridization probes. A library of mung bean cpDNA PstI and SalI restriction fragments cloned in the plasmid vector pBR322 served as hybridization probes to the filter-bound leafy spurge DNA fragments. This library, which covers almost the entire mung bean chloroplast genome (23) (Figure 1 ), has been thoroughly characterized (21) and used to study cpDNA of other species (6). Plasmids containing cpDNA inserts were isolated from $E$. coli hosts using a miniprep procedure (2). CpDNA inserts were removed from their plasmid vectors by restriction endonuclease digestion and were isolated on low melting point agarose gels. Probe bands were cut from the gels and incubated with $10 \mathrm{mM}$ Tris, $1 \mathrm{mM}$ EDTA buffer $(\mathrm{pH} 8)$ at $68 \mathrm{C}$ for $10 \mathrm{~min}$. The cpDNA was 


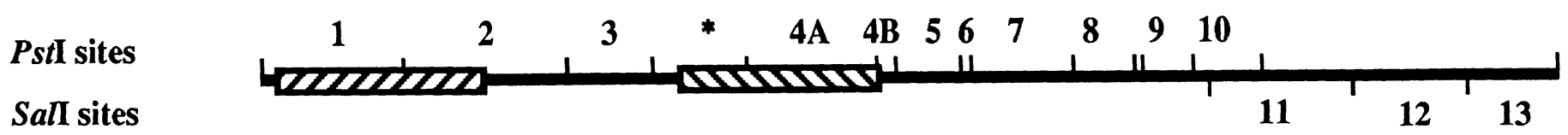

\section{Regions of collinearity between leafy spurge and mung bean cpDNA}

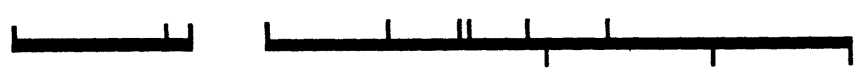

\section{* Probe not available for this segment of mung bean chloroplast genome.}

Figure 1. Arrangement of cpDNA probes along the mung bean chloroplast genome [shown in linear fashion for clarity of illustration; normally a circular molecule (21)]. Striped blocks show regions containing the inverted repeat. Regions of the leafy spurge cpDNA that are collinear with the mung bean chloroplast genome are shown.

labeled with digoxigenin-11-2'-deoxyuridine-5'-triphosphate (dUTP) using a random priming method (9). A commercially available nonradioactive labeling and detection kit $^{10}$ was used for analysis of Southern Blots. Final membrane washes were conducted at $68 \mathrm{C}$ with 2 times SSC buffer $(35.0 \mathrm{gm} \mathrm{NaCl}$ and $17.6 \mathrm{gm}$ sodium citrate $\left.\mathrm{L}^{-1}\right)$. Sizes of labeleơ filter-bound probes were determined by regression analysis using HindIIIdigested Lambda virus DNA as molecular weight markers (32).

\section{RESULTS AND DISCUSSION}

Total leafy spurge DNA, digested with EcoRI, yielded cpDNA fragments that strongly hybridized to each of the mung bean cpDNA probes. A total of $60 \mathrm{cpDNA}$ restriction fragments from each accession were visualized using the thirteen labeled mung bean cpDNA probes. EcoRI fragments that share regions of homology to adjacent mung bean probes were visualized twice in this analysis. Eight fragments hybridized by adjacent probes were judged to be overlapping fragments. Therefore, we estimate that each accession has 52 unique $E c o$ RI cpDNA fragments.

Analysis of cpDNA restriction fragment patterns provided evidence for colinearity between the mung bean and leafy spurge chloroplast genomes. The arrangement of probes in the mung bean chloroplast genome and regions of colinearity between mung bean and leafy spurge cpDNA are shown in Figure 1 . Colinearity was indicated by the observation that common fragments were hybridized by each pair of adjacent probes: $4 a$ and $4 b, 7$ and 8,8 and 9,11 and 12 .

Leafy spurge cpDNA size was estimated by summing the sizes of all nonoverlapping fragments (fragments that were not hybridized by two adjacent mung bean probes). Minimum

\footnotetext{
${ }^{10}$ DNA labeling and detection kit. Boehringer Mannheim Biochemicals, Indianapolis, IN.
}

estimates of chloroplast genome size for the five leafy spurge accessions examined ranged from 130 to $132 \mathrm{~kb}$. This is within the size range of 120 to $160 \mathrm{~kb}$ that has been established for most land plants (18). Structural colinearity and reasonable estimates of chloroplast genome size provided evidence that the mung bean cpDNA library was suitable for characterizing the leafy spurge cpDNA.

Polymorphisms among leafy spurge accessions. Examples of monomorphic and polymorphic cpDNA fragment patterns are shown in Figure 2. RFLPs were detected in five regions of the leafy spurge cpDNA (Table 2). Seven of the 13 mung bean cpDNA probes hybridized to polymorphic leafy spurge cpDNA fragments. Probes 10 and 11 shared regions of homology and identified the same polymorphic fragments, while probes 7 and 8 and probes 11 and 12 hybridized with overlapping polymorphic fragments (Figure 1). Variation in cpDNA EcoRI fragments detected with probes 5,7 or $8,9,10$ or 11 , and 11 or 12 can be explained by addition/deletion or rearrangement events.

Table 2. Sizes of polymorphic fragments of chloroplast DNA from selected leafy spurge accessions ${ }^{\mathrm{a}}$.

\begin{tabular}{lccccc}
\hline & \multicolumn{5}{c}{ Size of fragments hybridized by probe } \\
\cline { 2 - 6 } Accession & 5 & 7 or $8^{\mathrm{c}}$ & 9 & 10 or $11^{\mathrm{c}}$ & 11 or $12^{\mathrm{c}}$ \\
\hline & \multicolumn{6}{c}{ kilobase } \\
\cline { 2 - 6 } Nebraska & $2.3,2.1$ & 11.0 & $2.3,1.3$ & 1.4 & 5.5 \\
Montana & $2.3,2.1$ & 11.0 & $2.2,1.3$ & 1.4 & 5.5 \\
Russia & $2.3,2.1$ & 11.0 & $2.2,1.3$ & 1.4 & 5.5 \\
Italy & $2.3,2.1$ & 6.7 & $2.2,1.3$ & 3.9 & 5.5 \\
Austria & $2.2,2.2$ & 9.7 & $2.1,1.5$ & 1.4 & 5.1
\end{tabular}

${ }^{\text {a Total DNA was cut with EcoRI restriction endonuclease and analyzed }}$ by Southern blot hybridization.

${ }^{b}$ See Figure 1 for identification of mung bean probes.

${ }^{\mathrm{c}}$ Probes detecting overlapping polymorphic fragments. 

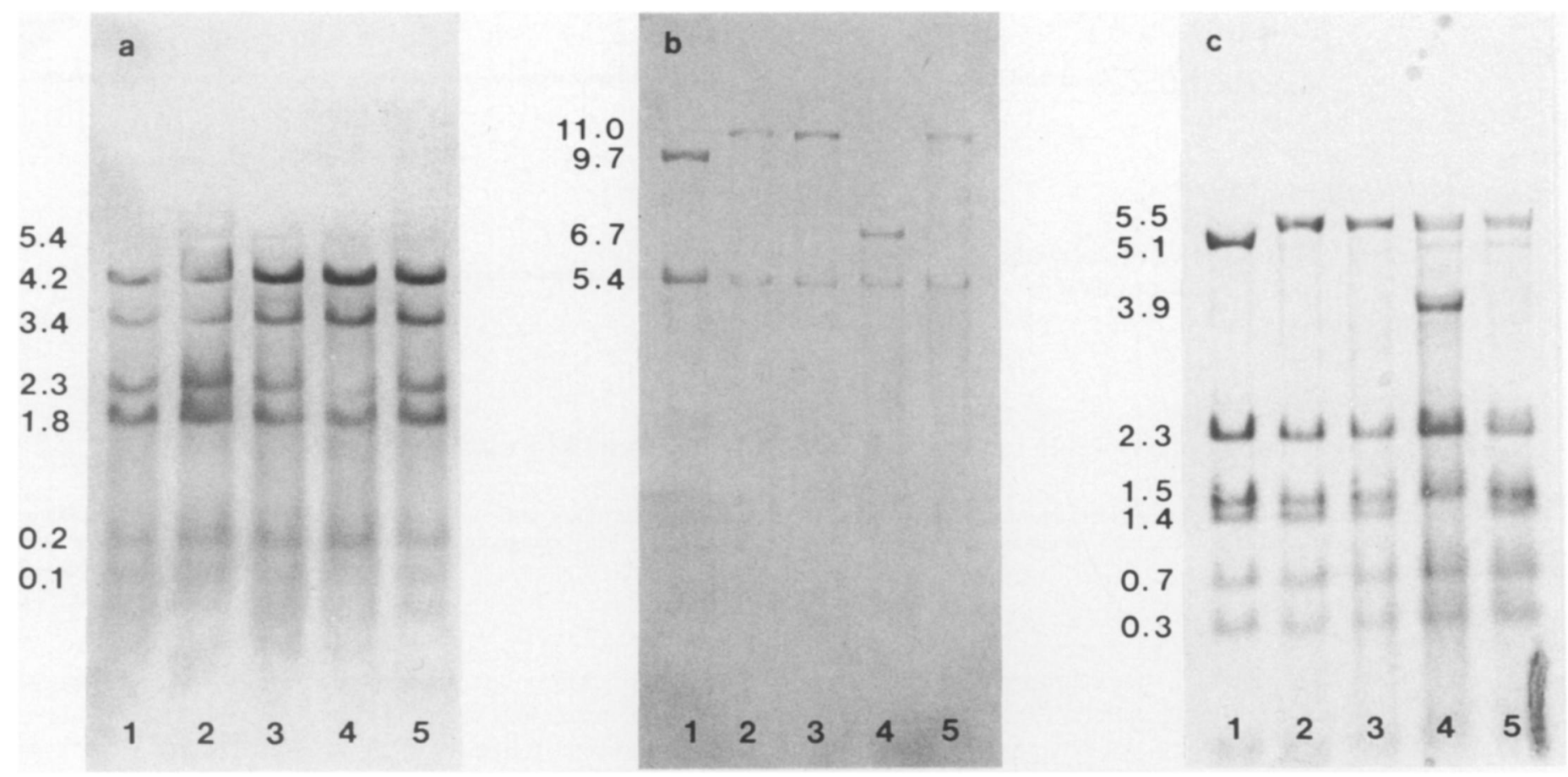

Figure 2. Examples of Southern blots obtained from total leafy spurge DNA digested with EcoRI. Blots were hybridized with cpDNA specific probes from mung beans: (a) probe \#1, (b) probe \#7, (c) probe \#11 (see Figure 1). Lane numbers indicate leafy spurge accessions as follows: $1=$ Austria, 2 = Nebraska, 3 = Montana, 4 = Italy, 5 = Russia. CpDNA fragments hybridized by probe \#1 were monomorphic, while probes \#7 and \#11 hybridized to several polymorphic cpDNA fragments of the Austrian and Italian accessions.

The Austria accession of leafy spurge was the most divergent accession evaluated. There were seven polymorphisms between the cpDNA of the Italy and Austria accessions and six polymorphisms between the Austria and Montana, Nebraska, and Russia accessions (Table 3). EcoRIgenerated fragment patterns of cpDNA of leafy spurge accessions from Montana and Russia were identical (Table 3). CpDNA from the Nebraska leafy spurge accession differed from the Montana and Russia accessions by a single unique fragment detected by probe 9 (Table 2). This fragment was 100 base pairs larger in the Nebraska accession.

Results of this study provided information about RFLPs in the cpDNA of five leafy spurge accessions. Based on structural colinearity and reasonable leafy spurge cpDNA size estimates, the mung bean cpDNA probes were appropriate for characterizing leafy spurge cpDNA. Identification of polymorphic fragments among the 52 unique EcoRI cpDNA fragments demonstrated that genetic differences exist among the five leafy spurge accessions evaluated. While morphological, micromolecular chemosystematic, and cytogenetic approaches to measuring genetic relationships within the leafy spurge complex have been largely unsuccessful, RFLP analysis of cpDNA promises to be a valuable technique for establishing the Eurasian origin of leafy spurge in North America.

Information gained from this work facilitates future studies which will include: determination of the mode of plastid inheritance in leafy spurge, development of a leafy spurge cpDNA map using additional restriction endonucleases, and identification of specific cpDNA probes and restriction endonuclease combinations for rapid assessment of genetic relatedness within and across populations of Eurasian and North American leafy spurge. Chloroplast inheritance is predominantly maternal in higher plants; therefore, cpDNA RFLP analysis will provide a significant amount of information about maternal lineage. Work is currently underway to use the randomly amplified polymorphic DNA technique to examine the variation in nuclear DNA. Establishing these genetic relationships will be essential for developing successful biological control programs. With this information, collection of biocontrol agents (insects and pathogens) could

Table 3. Number of cpDNA polymorphisms detected among leafy spurge accessions.

\begin{tabular}{lllcc}
\hline & \multicolumn{4}{c}{ Polymorphisms } \\
\cline { 2 - 5 } Accession & Austria & Italy & Russia & Montana \\
\hline & & & no. & \\
Nebraska & 6 & 3 & 1 & 1 \\
Montana & 6 & 2 & 0 & - \\
Russia & 6 & 2 & - & \\
Italy & 7 & - & & \\
\hline
\end{tabular}


be directed towards areas in Eurasia where the source of North American leafy spurge is found.

\section{ACKNOWLEDGMENTS}

We gratefully acknowledge C. Caha for assistance and consultation during plant sample analysis and $\mathrm{R}$. Bennett, $\mathrm{P}$. Fay, R. Frank, and R. Lym for providing leafy spurge accessions evaluated in this study. This research was supported by the University of Nebraska-Lincoln Research Council and NIH Biomedical Research Support Grant \#RR07055.

\section{LITERATURE CITED}

1. Bakke, A. L. 1936. Leafy spurge, Euphoriba esula L. Iowa Agric. Exp. Stn. Res. Bull. 198:209-245.

2. Birnboim, H. C. and J. Doly. 1979. A rapid alkaline extraction procedure for screening recombinant plasmid DNA. Nucleic Acid Res. 7:1513-1523.

3. Bowman, C. M., G. Bonnard, and T. A. Dyer. 1983. Chloroplast DNA variation between species of Triticum and Aegilops: Location of the variation on the chloroplast genome and its relevance to the inheritance and classification of the cytoplasm. Theor. Appl. Genet. 65:247-262.

4. Coates, D. and C. A. Cullis. 1987. Chloroplast DNA variability among Linum species. Am. J. Bot. 74:260-268.

5. Curtis, S. E. and M. T. Clegg. 1984. Molecular evolution of chloroplast DNA sequences. Mol. Biol. Evol. 1:291-301.

6. Doyle, J. J., J. L. Doyle, A.H.D. Brown, and J. P. Grace. 1990. Multiple origins of polyploids in the Glycine tabaciana complex inferred from chloroplast DNA polymorphism. Proc. Nat. Acad. Sci., U.S.A. 87:714-717.

7. Ebke, D. H. and M. K. McCarty. 1983. A nursery study of leafy spurge (Euphorbia spp.) complex from North America. Weed Sci. 31: 866-873.

8. Erickson, L. R., N. A. Straus, and W. D. Beversdorf, 1983. Restriction patterns reveal origins of chloroplast genomes in Brassica amphidiploids. Theor. Appl. Genet. 65:201-206.

9. Feinberg, A. P. and B. Vogelstein. 1983. A technique for radiolabelling DNA restriction endonuclease fragments with high specific activity. Anal. Biochem. 132:6-13.

10. Garber, E. D. 1972. Cytogenetics: An Introduction. McGraw-Hill, New York. Pages 227-244.

11. Harris, P., P. H. Dunn, D. Schroeder, and R. Vanmoos. 1985. Biological control of leafy spurge in North America. Pages 79-82 in A. K. Watson, ed. Leafy spurge. Monogr. No. 3. Weed Sci. Soc. Am., Champaign, IL.

12. Harvey, S. J., R. M. Nowerski, P. G. Mahlberg, and J. M. Story. 1988. Taxonomic evaluation of leaf and latex variability of leafy spurge (Euphorbia spp.) for Montana and European accessions. Weed Sci. 36: 726-733.

13. Kung, S. D., Y. S. Zhu, and G. F. Shen. 1982. Nicotiana chloroplast genome. III. Chloroplast DNA evolution. Theor. Appl. Genet. 61: 73-79.

14. Mahlberg, P. G., D. G. Davis, D. S. Galitz, and G. D. Manners. 1987. Laticifers and the classification of Euphorbia: The chemotaxonomy of Euphorbia esula L. Bot. J. Linn. Soc. 94:165-180

15. Maniatas, T., E. F. Fritsch, and J. Sambrook. 1989. Chapter 6 in Molecular cloning, a laboratory manual. Cold Spring Harbor Lab., Cold Spring Harbor, NY

16. Manners, G. D. and D. G. Davis. 1984. Epicuticular wax constituents of North American and European Euphorbia esula biotypes. Phytochemistry 23:1059-1062.

17. Morton, C. V. 1937. The correct name of leafy spurge. Rhodora 39: $49-50$.
18. Palmer, J. D. 1985. Comparative organization of chloroplast genomes. Annu. Rev. Genet. 19:325-354.

19. Palmer, J. D. 1987. Chloroplast DNA evolution and biosystematic uses of chloroplast DNA variation. Am. Nat. 130:S6-S29.

20. Palmer, J. D., R. A. Jorgensen, and W. F. Thompson. 1985. Chloroplast DNA variation and evolution in Pisum: Patterns of change and phylogenetic analysis. Genetics 109:195-213.

21. Palmer, J. D., B. Osorio, and W. F. Thompson. 1988. Evolutionary significance of inversions in legume chloroplast DNAs. Curr. Genet. 14:65-74.

22. Palmer, J. D., C. R. Shields, D. B. Cohen, and T. J. Orton. 1983. Chloroplast DNA evolution and the origin of amphidiploid Brassica. Theor. Appl. Genet. 65:181-189.

23. Palmer, J. D. and W. F. Thompson. 1981. Clone banks for mung bean, pea, and spinach chloroplast genomes. Gene 15:21-26.

24. Palmer, J. D. and W. F. Thompson. 1982. Chloroplast DNA rearrangements are more frequent when an inverted repeat sequence is lost. Cell 29:537-550.

25. Palmer, J. D. and D. Zamir. 1982. Chloroplast DNA evolution and phylogenetic relationships in Lycopersicon. Proc. Nat. Acad. Sci., U.S.A. 79:5006-5010.

26. Perl-Treves, R. and E. Galun. 1985. The Cucumis plastome: Physical map, intrageneric variation and phylogenetic relationships. Theor. Appl. Genet. 71:417-429.

$: \rightarrow$ Radcliffe-Smith, A. 1981. New combinations in the genus Euphorbia: III. Kew Bull. 36:216.

28. Radcliffe-Smith, A. 1985. Taxonomy of North American leafy spurge. Pages 14-25 in A. K. Watson, ed. Leafy spurge. Monogr. No. 3. Weed Sci. Soc. Am., Champaign, II.

29. Reed, K. C. and D. A. Mann. 1985. Rapid transfer of DNA from agarose gels to nylon membranes. Nucleic Acid Res. 13:7207-7221.

30. Saghai-Maroof, M. A., K. M. Soliman, R. A. Jorgensen, and R. W. Allard. 1984. Ribosomal DNA spacer-length polymorphisms in barley: Mendelian inheritance, chromosomal location, and population dynamics. Proc. Nat. Acad. Sci., U.S.A. 81:8014-8018.

31. Salts, Y., R. G. Herrmann, N. Peleg, U. Lavi, S. Izhar, R. Frankel, and J. S. Beckman. 1984. Physical mapping of plastid DNA variation among Nicotiana species. Theor. Appl. Genet. 69:1-14.

32. Schaffer, H. E. and R. R. Sederoff. 1981. Improved estimation of DNA fragment lengths from agarose gels. Anal. Biochem. 115:113-122.

33. Schulz-Schaeffer, J. and S. Gerhardt. 1987. Cytotaxonomic analysis of the Euphorbia spp. ("Leafy spurge") complex. Biol. Zentralbl. 106: $429-438$.

34. Sederoff, R. R. 1984. Structural variation in mitochondrial DNA. Adv. Genet. 22:1-108.

35. Sytsma, K. J. and L. D. Gottlieb. 1986. Chloroplast DNA evidence for the origin of the genus Heteroguara from a species of Clarkia (Onagraceae). Proc. Nat. Acad. Sci., U.S.A. 83:5554-5557.

36. Terachi, T., Y. Ogihara, and K. Tsunewaki. 1984. The molecular basis of genetic diversity among cytoplasms of Triticum and Aegilops. III. Chloroplast genomes of the $\mathbf{M}$ and modified $\mathbf{M}$ genome-carrying species. Genetics 108:681-695.

37. Torell, J. M., J. O. Evans, R. V. Valcarce, and G. G. Smith. 1989. Chemical characterization of leafy spurge (Euphorbia esula L.) by curie-point pyrolysis-gas chromatography-pattern recognition. J. Anal. Appl. Pyrolysis 14:223-236.

38. Tsunewaki, K. and Y. Ogihara. 1984. The molecular basis of genetic diversity among cytoplasms of Triticum and Aegilops. II. On the origin of polyploid wheat cytoplasms as suggested by chloroplast DNA restriction fragments. Genetics 104:155-171.

39. Watson, A. K., ed. 1985. Leafy spurge. Pages 1-7 in Monogr. No. 3. Weed Sci. Soc. Am., Champaign, IL.

40. Wheeler, L. C. 1939. A miscellany of the new world Euphorbiaceae-II. Contrib. Gray Herb. 127:48-78.

41. Whitfield, P. R. and W. Bottomley. 1983. Organization and structure of chloroplast genes. Annu. Rev. Plant Physiol. 34:279-310. 